\title{
Biologic and Ecologic Aspects of Sinelobus stanfordi (Richardson, 1901) (Crustacea, Tanaidacea) in the Martín García Island Natural Reserve, Río de la Plata, Argentina
}

\author{
I. I. César ${ }^{1^{*}}$ and R. V. Becerra ${ }^{2}$ \\ ${ }^{1}$ Department of Biology, Faculty of Exact and Natural Sciences, Marine and Coastal Research \\ Institute, National University of Mar del Plata, Dean Funes 3350, Argentina. \\ ${ }^{2}$ Biochemical Researches Institute of La Plata (CONICET), Argentina.
}

\begin{abstract}
Authors' contributions
This work was carried out in collaboration between both authors. Author IIC designed the study, performed the statistical analysis, wrote the protocol, and wrote the first draft of the manuscript.

Author RVB managed the analyses of the study. Both authors read and approved the final

manuscript.

Article Information

DOI: 10.9734/ARRB/2019/v31i330048

Editor(s):

(1) Dr. Amit Kesarwani, Assistant Professor, Department of Agronomy, College of Agriculture, G.B. Pant University of Agriculture \& Technology, India.

(2) Dr. George Perry, Dean and Professor of Biology, University of Texas at San Antonio, USA.

Reviewers:

(1) Moses Mwajar Ngeiywa, University of Eldoret, Kenya.

(2) Ali Türker, Mugla Sitki Kocman University, Turkey.

Complete Peer review History: http://www.sdiarticle3.com/review-history/48081
\end{abstract}

Original Research Article

Received 28 December 2018

Accepted 13 March 2019

Published 26 March 2019

\section{ABSTRACT}

We investigated the biology and ecology of the tanaidacean Sinelobus stanfordi from the littoral water of Martín García Island at five sites along the coast chosen for their substrate characteristics, and classified the individuals according to size $(\mathrm{mm})$ and ectosomatic characterinalysisstics as: manca III (0.60-1.19), juvenile male and female I (0.90-1.49), juvenile female II and copulatory male I (1.2-1.79), preparatory female I (1.8-2.39), preparatory female II (2.40-2.99), copulatory female I (2.40-2.69), copulatory female II (2.99-4.19), ovigerous female (1.80-3.59), copulatory male II (1.51.79), copulatory male III (2.10-2.69) and copulatory male IV (2.40-3.89). The smallest female with rudimentary ovisacs measured $1.84 \mathrm{~mm}$. The tanaid density ranged from 0 to 10,548 ind. $\mathrm{m}^{-2}$. The average female-to-male sex ratio was 3.04:1. An abundance analysis indicated no significant

*Corresponding author: E-mail: icesar@mdp.edu.ar; 
differences among the sampling sites $\left(X^{2}=4.037, p>0.001\right)$, while the fecundity (number of eggs) did not vary significantly with female size $\left(r^{2}=0.2164, n=19\right)$. The almost permanent presence of all developmental stages during every season of the year suggested a likely continuous year-long reproduction of $S$. stanfordi. Relationship between the water variables and $S$. stanfordi populations: The lower than optimal average electrical conductivity $\left(160.24 \mu \mathrm{S} . \mathrm{cm}^{-1}\right)$ for the species did not seem to limit the population-growth kinetics. The postmarsupial development throughout almost all the stages evidenced a significant positive correlation with $\mathrm{pH}$. The soluble-reactive-phosphorus levels were within the low tolerance values as well as the $\mathrm{NO}^{-3}$ and the $\mathrm{NH}_{4}{ }^{+}$and both close to optimal along with the near-optimal percent saturation of oxygen.

Keywords: Sinelobus stanfordi; nature reserve; biology; ecology; environmental variables.

\section{ABBREVIATIONS}

$\begin{array}{ll}\text { MJuv I } & \text { : Male Juvenil I } \\ \text { CopM I } & \text { : Copulatory Male I } \\ \text { CopM II } & \text { : Copulatory Male II } \\ \text { CopM III } & \text { : Copulatory Male III } \\ \text { CopM IV } & \text { : Copulatory Male IV } \\ \text { JuvF I } & \text { : Female Juvenil I } \\ \text { JuvF II } & \text { : Female Juvenil II } \\ \text { PrepF I } & \text { : Preparatory Female I } \\ \text { PrepF II } & \text { : Preparatory Female II } \\ \text { CopF I } & \text { : Copulatory Female I } \\ \text { CopF II } & : \text { Copulatory Female II } \\ \text { OvF } & : \text { Ovigerous Female } \\ \text { SD } & : \text { Standard Deviation }\end{array}$

\section{INTRODUCTION}

The Nature Reserve of Martín García island situated in the confluence of the Uruguay and Paraná rivers (Upper Río de la Plata estuary) and constitutes an outcropping of the precambrian crystalline basement [1]. The littoral zone of the island contains wide diversity of substrates that provide many opportunities for faunal colonization. Examples of several recent publications on the invertebrate biota of this natural reserve have concerned the platyhelminth temnocephala [2], the aquatic oligochaetes [3,4,5], the hirudinea [6], the aquatic and semiaquatic insects [7], the ostracod crustaceans $[8,9,10,11]$, the aquatic mollusks $[12,13,14,15,16,17]$, and the terrestrial mollusks [18].

The particular geographical location of Martín García island, its status as a natural reserve, and its frequentation by tourists -even apart from its ecology and the taxonomy of this fauna -make this island a study area of extreme interest.

The aim of the work reported here was therefore to investigate the biologic and ecologic features of Sinelobus stanfordi (Richardson) a cosmopolitan, euryhaline peracarida crustacean inhabiting the littoral waters of the island.

\section{MATERIALS AND METHODS}

\subsection{The Study Sites}

The coastline around the island of Martín García is asymmetrical (Fig. 1).

The western and northern shores constantly receive silty material that becomes deposited on the rocky bottom to be and is subsequently consolidated by vegetation. The eastern and southern shorelines are rocky; and, because of strong southeasterly winds, this portion of the coast becomes covered by silt-sand deposits only occasionally. The shoreline asymmetry results in a differential distribution of vegetation: along the northern shore (Site 4), areas containing a reedy type of vegetation are prevalent, composed of approximately 16 different species of hydrophytes (e.g., Typha latifolia L., Echinodorus grandiflorus (Cham \& Schtdl.) Micheli, Panicum pernambucense (Spreng.) Mez ex Pilg., Cyperus virens Michx., Pontederia rotundifolia L.f., Ludwigia elegans (Cambess.) Hara, Alternanthera philoxeroides (Mart.) Griseb, and Ranunculus flageliformis (Sm.). The submerged vegetation -such as Potamogeton gayii A. Benn, Egeria densa Planch, and Myriophyllum aquaticum (Vell.) Verdc., grows in the permanently flooded areas of the reedy sectors [19].

Site 5, on the western coast, is an area containing sand-silt sediments and bordering an anthropic garbage- disposal area. Site 1, lying towards the southern coast of the island, is sandy and supporting only a few reedy areas containing Schoenoplectus californicus (C. A. Mey.) Soják. Site 2, on the southeastern coast, is a small beach of clean sand; while Site 3, farther north along the coast, constitutes an extensive 
area with reeds with S. californicus growing from sand-silt sediments.

\subsection{The Sampling}

The sampling was conducted on eight occasions from autumn of 1995 into the winter 1997 (i. e., 03/95, 05/95, 08/95, 11/95, 03/96, 11/96, 03/97 and $06 / 97$ ). The five sites along the entire coast were chosen according to their substrate characteristics: fine sands, silty sands, reeds, and silted areas with a great development of hydrophytes. The samples (three replicates per site), removed with an Eckman hand dredge (225 $\left.\mathrm{cm}^{2}\right)$, were fixed in $10 \%(\mathrm{v} / \mathrm{v})$ aqueous formaldehyde. The depths of the sampling ranged from ca. 0.30 to 1 meter. The various habitat physical and water quality parameters were assessed and measured (Table 1) according to [20].

\subsection{The Samples Processing}

The processing of the samples in the laboratory included either washing plus sieving, through a $125 \square \mathrm{m}$ mesh screen or the flotation techniques of [21] for sandy substrata; with the specific methodology depending on the dominant substrate of each sample.

The sieved flotation-isolated material was then dyed with Bengal pink (24 h). Sinelobus. stanfordi specimens $(n=1,594)$ were analysed quantitatively and qualitatively using binocular sterescopic microscop and binocular optic microscope. The total length of each individual was measured from the anterior tip of the carapace to the posteromedial margin of the pleotelson, under a steromicroscope with a micrometer in the ocular.

The life- cycle stages of this gonochoristic species [22] were classified according to those authors into: egg, manca I (i. e., hatchling, inside the maternal marsupium), manca II, manca III, juvenile male I, juvenile female I, Juvenile Female II, copulatory males I - IV, preparatory female I and II, copulatory female I and II with the last three being free-living stages. Females with and without ovisacs, those with eggs in the ovisacs, and males could also be identified among the adult animals.

\subsection{The Statistical Analyses}

We applied the Kruskal-Wallis and the $\mathrm{Chi}^{2}$ tests $\left(X^{2}\right)$ were applied to compare the abundance among the different sampling sites and to analyze the sex-ratio [23]. Conducted the Pearson correlation analysis between the environmental variables and the developmental stages was conducted and determined the statistical-significance values of the correlations determined by the Student $t$ test.

Table 1. Sinelobus stanfordi density in the Isla Martín García littoral

\begin{tabular}{llllll}
\hline Sampling date & Site & \multicolumn{2}{l}{ Density $\left(\right.$ ind. $\left./ \mathbf{m}^{2}\right)$} & Mean abundance SD & Number of samples \\
\hline Summer 1995 & 3 & 3511.11 & 79 & 93.3435 & 3 \\
\hline Autumn 1995 & 3 & 1496.3 & 33.66 & 56.5891 & 3 \\
& 4 & 326 & 7.33 & 8.3864 & 3 \\
& 5 & 10548.14 & 237.33 & 274.05 & 3 \\
\hline Winter 1995 & 1 & 252 & 5.66 & 9.8149 & 3 \\
& 3 & 711.11 & 16 & 22.5385 & 3 \\
& 5 & 29.63 & 0.66 & 1.1547 & 3 \\
\hline Spring 1995 & No specimens & & & 3 \\
\hline Summer 1996 & 1 & 89 & 2 & 1.732 & 3 \\
& 3 & 326 & 7.33 & 12.7017 & 3 \\
\hline Spring 1996 & 1 & 2518.52 & 56.66 & 31.1341 & 3 \\
& 3 & 1541 & 34.66 & 39.7156 & 3 \\
& 5 & 104 & 2.33 & 2.5166 & 3 \\
\hline Summer 1997 & No specimens & & & 3 \\
\hline Autumn 1997 & 3 & 2430 & 54.66 & 38.8873 & 3 \\
& 4 & 15 & 0.33 & 0.5773 & 3 \\
& 5 & 44.44 & 1 & 1 & 3 \\
\hline
\end{tabular}

The density of (Table 1.) ranged from 0 to a maximum of 10,548 ind. $m^{-2}$ at Site 5 in the autumn 1995 

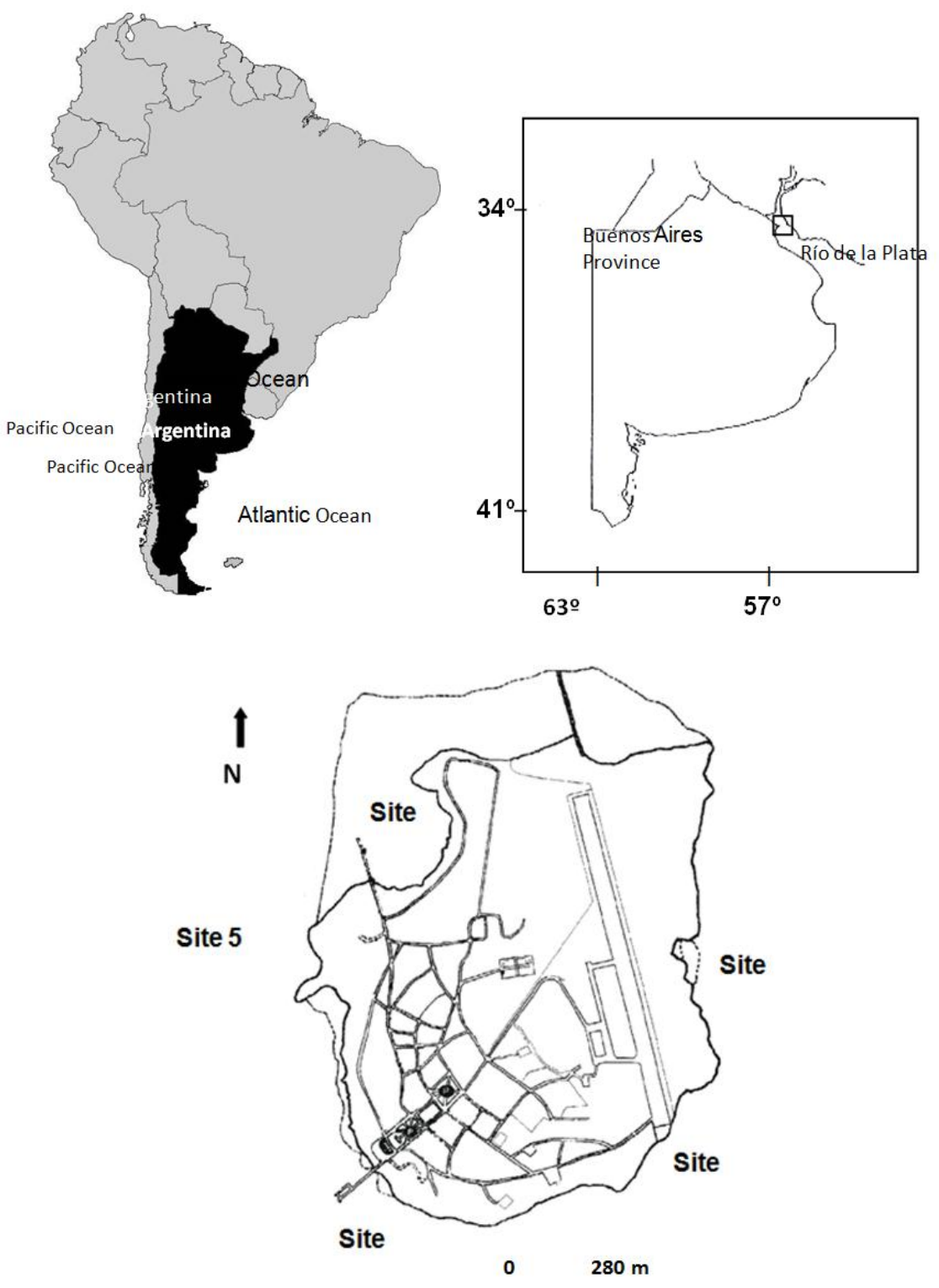

Fig. 1. Map showing the sampling sites at the Martín García Island Nature Reserve. Upper left panel: Location of Argentina (black) within South America. Inset in the upper right: Location of Martin García Island in the northeastern most portion of the Río de La Plata estuary between Argentina and Uruguay (boxed area). Lower panel: Map of the island indicating the positions of the five littoral study sites.

\section{RESULTS}

\subsection{General Observations}

In the field the following postmarsupial stages of development were found (Fig. 2): Manca III, juvenile male I (JuvM I), juvenile female I (JuvF
I), juvenile female II (JuvF II),copulatory male I (CopM I), preparatory female I (PrepF I), preparatory female II (PrepF II), copulatory female I (CopF I), copulatory female II (CopF II), copulatory male II (CopM II), copulatory male III (CopM III), copulatory male copulatory male IV (CopM IV) and ovigerous female (OVF). 

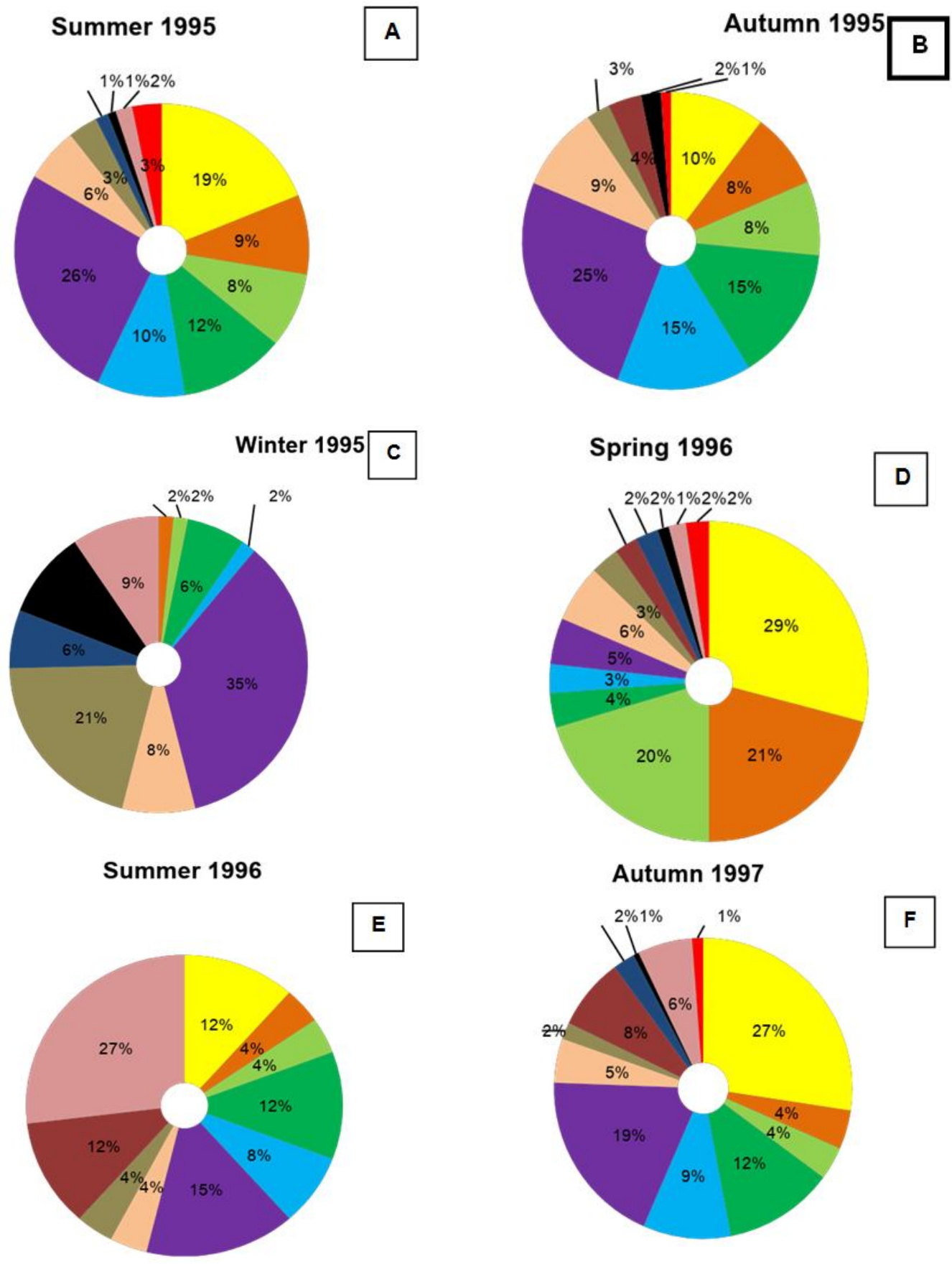

Fig. 2. Relative abundance of the postmarsupial life-cycle stages of Sinelobus stanfordi population at the Martín García Island Nature Reserve during the study period: Panel A, Summer 1995; Panel B, Autumn 1995; Panel C, Winter 1995; Panel D, Spring 1996; Panel E, Summer 1996 and Panel F, Autumn 1997. Key to the colors in the pie charts corresponding to the percent proportions of the different life-cycle stages indicated outside the circle: Manca III,$\Delta$ JuvM I, $\Delta$ J JuvF I, $\mathbf{\Delta}$; JuvF II $\mathbf{\Delta} ; \operatorname{CopM~I,~} \mathbf{\Delta}$ CopM, II, $\mathbf{\Delta}$ CopM III, $\mathbf{\Delta}$ CopM IV, $\Delta$ PrepF I, $\boldsymbol{\Delta}$ PrepF II, $\Delta$ CopF I, $\Delta$ CopF II, $\Delta$ OOVF, $\boldsymbol{\Delta}$ 


\subsection{Abudance of Life-cycle Stages throughout the Study Period}

\subsubsection{Abundance peaks}

The highest percentages of Manca III stage were recorded during the Spring of 1996 (Fig. 2 Panel D) and the Autumn of 1997 (Fig. 2 Panel F), while the highest percentages of FJuv I and MJuv I were also recorded in Spring of 1996 (Fig. 2 Panel D).

\subsubsection{Spring 1995}

Sinelobus stanfordi was absent at all the sampling sites during the spring 1995.

\subsubsection{Summer 1995}

In the summer of 1995 (Fig. 2, Panel A), the relative abundance of $\mathrm{S}$. stanfordi population contained $48 \%$ larval forms and $52 \%$ individual with varying degrees of reproductive maturity. Although almost stages were present, PrepF I and II and CopM I were the most abundant, whereas the OVF were scarce.

\subsubsection{Autumn 1995}

In the autumn of 1995 (Fig. 2, Panel B), the abundances of larval forms (Manca III, JuvF I and II, and JuvM I) were similar to those reported during the summer. The relative abundance of individuals suitable for breeding has increased to $58 \%$ over the summer, although the proportion of CopM IV stage was is low, the population also contained $18 \%$ sexually mature individuals of stage CopM I [22]. Reproduction clearly took place in April, which period was notable with respect to the recruitment of the Manca III, JuvM I, JuvF I and II stages. The abundance of the PrepF I and II and CopF I and II females represented a $41 \%$ of the population. The occurrence of females with eggs and of the CopM IV stage was still scarce.

\subsubsection{Winter 1995}

The JuvM I and JuvF I and II stages were present during the winter of 1995 (Fig. 2, Panel C) $(10 \%)$, whereas no Manca III stages were recorded during that period. With respect to all the sampling occasions, the highest values for PrepF I and II and the CopF I and II stages were recorded during the winter of that year, but the general population density was notably low (Table 1.). No females with eggs in the marsupia were found and the CopM II and CopM IV stages represented $18 \%$ of the population.

\subsubsection{Spring and summer 1996}

The population density was low in the summer of 1996 (Table 1). The Manca III, JuvM I, and JuvF I and II stages-having passed through a maximum density in the of 1996 at a total abundance of $70 \%$-by the summer of that year all together represented only $30 \%$ of the population. Instead, this season featured a dominance of CopM IV, followed by the stages PrepF I and II, and CopF I and II, with the othe being present at only low values.

\subsubsection{Autumn 1997}

Subsequently during the autumn of 1997, a recruitment of the Manca III and the JuvM I and II stages took place. At that time, the PrepF I and II stages were present in the population while the stages CopF I and II represented only a respective 2 and $8 \%$ along with the Fov at but a low $1 \%$. At that time, all of the stages of the males together constituted $18 \%$ of the total population.

\subsubsection{Abundance troughs}

No individuals were recorded in the spring 1995 or in the summer of 1997. This phenomenon agreed with the presence of strong southeasterly winds in the area at that time.

\subsubsection{Abundance analysis}

The analysis of abundance demonstrated that no significant differences occurred among the sampling sites $\left(X^{2}=4.037, p>0.001\right)$. Site 3 , though, was the most constant as regards the presence of $S$. stanfordi over the entire study period followed by Site 1 (Table 1).

\subsubsection{Population density}

The density of $S$. stanfordi in Martín Garcia island (Table 1) ranged from 0 to a maximum of 10,548 ind. $\mathrm{m}^{-2}$ at Site 5 in the autumn 1995.

\subsection{Size Distribution}

Fig. 3 summarizes the size distribution of the developmental stages of both the females and the males in the field (measurements in $\mathrm{mm}$ ): The size ranges for the various postmarsupialfemale stages were the following:

The Manca III from 0.60 to 1.19 , the JuvM I and the JuvF I, from 0.90 to 1.49 , the JuvF II and CopM I from 1.2 to 1.79 , the PrepF I from 1.8 to 

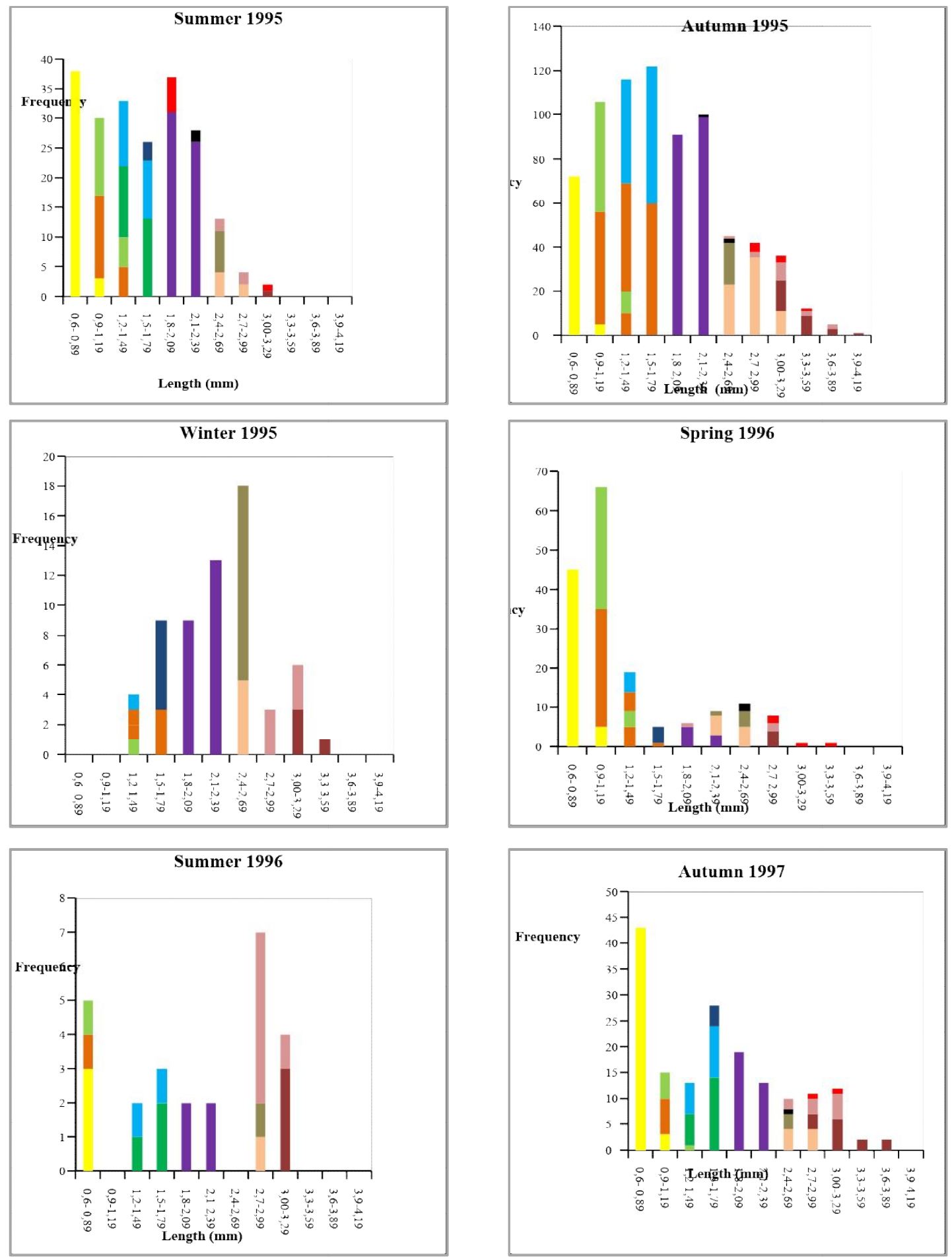

Fig. 3. Size distribution of the postmarsupia life-cycle stages of the Sinelobus stanfordi population at the Martín García Island Nature Reserve. Manca III, $\Delta$; JuvM I, $\Delta$; JuvF I, $\Delta$;

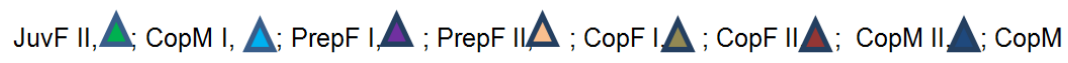
$\mathrm{III}, \mathbf{\Lambda} ; \mathrm{CopM} \mathrm{IV}, \mathbf{\Delta}$ OVF, $\mathbf{\Delta}$ 
2.39, the PreFp II from 2.4 to 2.99 , the CopF I from 2.4 to 2.69 , CopF II from 2.99 to 4.19 and the OVF from 1.8 to 3.59 . The size range of the copulatory males, for their part, varied as follows: the CopM II, from 1.5 to 1.79 , the CopM III from 2.1 to 2.69, and the CopM IV from 2.4 to 3.89 .

\subsection{Sex Ratios}

In the summer of 1995, the sex ratio was significantly skewed from the expected Mendelian value of 1:1 $\left(X^{2}=55.06, p<0.001\right)$ as well as in the autumn and winter of the same year $\left(X^{2}=205.44, p<0.001 ; X^{2}=19.64, p<\right.$ 0.001 , respectively). No significant deviations for the sex ratio were recorded during the summer and spring of $1996\left(X^{2}=0.42, p>0.001 ; X^{2}=\right.$ $3.64, p>0.001$, respectively) or in the autumn of $1997\left(X^{2}=8.76, p>0.001\right)$. The average sex ratio over all was 3.04: 1 in favor of the females.

\subsection{Fecundity}

Throughout all the sampling occasions, a total of 19 females (range of tolal length of ovigerous females were from 1.97 to 3.55 were recorded with eggs in the marsupia. The number of eggs in those individuals ranged from 4 to 26 at an average value of 12.53 (SD 6.6279).

\subsection{Environmental Parameters Abundance Correlations}

The average values of the environmental variables during the study period in the Nature Reserve were the following: temperature, $21.7^{\circ} \mathrm{C}$ ( $S D=6.24)$; electrical conductivity. $122.4 \mu \mathrm{cm}^{-1}$ $(\mathrm{SD}=30.01)$; dissolved oxygen, $8.16 \mathrm{mg} \mathrm{L}^{-1}$ $(\mathrm{SD}=2.69) ; \mathrm{pH}, 7.25$ (SD=1.08); ammonium,17.0 $\mu \mathrm{g} \mathrm{L}{ }^{-1} \quad$ (SD=5.86); nitrate, $167.33 \mu \mathrm{m} \mathrm{L}^{-1}$ $(\mathrm{SD}=53.42)$; soluble reactive phosphorus, 66.88 $\mu \mathrm{g} \mathrm{L} \mathrm{L}^{-1} \quad(\mathrm{SD}=28.16) ;$ calcium, $7.98 \mathrm{mg} \mathrm{L}^{-1}$ ( $\mathrm{SD}=0.91)$; magnesium, $3.84 \mathrm{mg} \mathrm{L}^{-1}(\mathrm{SD}=0.81)$; sodium, $12,45 \mathrm{mg} \mathrm{L}^{-1}(\mathrm{SD}=3.75)$; potassium, 2,5 $\mathrm{mg} \mathrm{L}^{-1}(\mathrm{SD}=0.12)$; bicarbonate, $42.1 \mathrm{mg} \mathrm{L}^{-1}$ $(\mathrm{SD}=5.89)$; total phosphorus, $174.2 \mathrm{mg} \mathrm{L}^{-1}$ $(S D=53.55)$; total organic carbon, $5.31 \mathrm{mg} \mathrm{L}^{-1}$ $(\mathrm{SD}=1.31)$; sulfate, $4.88 \mathrm{mg} \mathrm{L}^{-1}(\mathrm{SD}=0.25)$ and suspended material, $47.4 \mathrm{mg} \mathrm{L}^{-1}(\mathrm{SD}=20.89)$.

A Pearson correlation analysis between developmental stages and the environmental variables measured (Table 2.) indicated that the
Manca III stage exhibited high positive correlations with $\mathrm{Ca}^{2+}$, the total phosphorous, $\mathrm{HCO}_{3}{ }^{-}$, and the total organic carbon along with a significant positive correlation with the $\mathrm{pH}$, while the JuvM I and JuvF I stages were highly associated positively with the temperature, $\mathrm{Ca}^{2+}$ and $\mathrm{Mg}^{+2}$ ions, the total phosphorous, $\mathrm{HCO}^{-}$ ${ }^{3}$, and the total organic carbon as well as being significantly correlated positively with the $\mathrm{pH}$. The JuvF II stage evidenced a high positive association with the temperature, $\mathrm{Mg}^{+2}, \mathrm{HCO}^{-3}$ and the total phosphorous and was significantly correlated positively with the $\mathrm{pH}$.

The PrepF I and II stages both exhibited high positive correlations with the temperature, $\mathrm{Mg}^{+2}$, $\mathrm{HCO}_{3}{ }^{-}$and the total phosphorous and were significantly correlated positively with the $\mathrm{pH}$, as was the PrepF I with the $\mathrm{Ca}^{2+}$ ion. The CopF I stage evidenced a high positive association with the $\mathrm{NH}_{4}^{+}, \mathrm{Ca}^{2+}, \mathrm{Mg}^{+2}$, and $\mathrm{HCO}^{-3}$ ions along with the total with the temperature.

The CopF II stage manifested the same associations as the CopF I but, the correlation with the temperature was highly positive and the association with the $\mathrm{pH}$ significant.

The OvF stage exhibited high positive correlations with the temperature, total phosphorous, and $\mathrm{HCO}^{-3}$ and total organic carbon along with a significant positive association with the $\mathrm{pH}$.

The CopM I stage manifested high positive correlations with the temperature, the $\mathrm{Mg}^{+2}$ and $\mathrm{HCO}^{-3}$ ions and the total phosphorous along with being significantly correlated positively with the $\mathrm{pH}$. The CopM II stage exhibited high positive correlations with the dissolved-oxygen concentration; the $\mathrm{NH}^{4+}, \mathrm{Ca}^{2+}$ and $\mathrm{HCO}^{-3}, \mathrm{SO}_{4}{ }^{2-}$ ions, and the total phosphorous and total organic carbon. Furthermore, the correlation of that stage with the $\mathrm{Na}^{+}$ion was both positive and significant. The CopM III stage was highly associated positively with the $\mathrm{Ca}^{2+}, \mathrm{Mg}^{2+}$ and $\mathrm{HCO}^{-3}$ ions along with the total phosphorous and total organic carbon. Moreover that stage manifested a significant positive and correlation with the temperature and the $\mathrm{pH}$; while, the CopM IV stage exhibited high positive associations with the $\mathrm{NH}^{4+}, \mathrm{Ca}^{2+}$ and $\mathrm{HCO}^{-3}$ ions as well as with the total phosphorous and total organic carbon in addition to a correlation with the dissolved-oxygen concentration that was positive and significant. 
César and Becerra; ARRB, 31(3): 1-14, 2019; Article no.ARRB.48081

Table 2. Pearson correlation analysis between developmental stages and the environmental variables

\begin{tabular}{|c|c|c|c|c|c|c|c|c|c|c|c|c|c|c|c|c|}
\hline & $\mathrm{T}^{\circ} \mathrm{C}$ & EC & DO & $\mathrm{pH}$ & $\mathrm{NH}_{4}^{+}$ & $\mathrm{NO}_{3}{ }^{-}$ & SRP & $\mathrm{Ca}^{2+}$ & $\mathrm{Mg}^{2+}$ & $\mathrm{Na}^{+}$ & $\mathrm{K}^{+}$ & $\mathrm{HCO}_{3}^{-}$ & TP & TOC & $\mathrm{SO}_{4}{ }^{2-}$ & SM \\
\hline Ma III & 0.24 & -0.25 & 0.13 & ${ }^{*} 0.28$ & ${ }^{\star \star} 0.37$ & -0.08 & ${ }^{*}-0.27$ & ${ }^{* \star} 0.52$ & ${ }^{*} 0.30$ & 0.15 & -0.21 & ${ }^{* *} 0.61$ & ${ }^{\star \star} 0.83$ & ${ }^{\star *} 0.61$ & 0.17 & ${ }^{* *}-0.47$ \\
\hline JuvM I & ${ }^{* *} 0.51$ & ${ }^{*}-0.30$ & -0.14 & ${ }^{*} 0.32$ & 0.19 & -0.24 & -0.25 & ${ }^{* *} 0.41$ & ${ }^{* *} 0.55$ & 0.04 & ${ }^{* *}-0.46$ & ${ }^{* *} 0.54$ & ${ }^{* \star} 0.92$ & ${ }^{* *} 0.49$ & -0.02 & ${ }^{* *}-0.50$ \\
\hline JuvF I & ${ }^{* *} 0.54$ & ${ }^{*}-0.29$ & -0.17 & ${ }^{*} 0.32$ & 0.16 & ${ }^{*}-0.27$ & -0.24 & ${ }^{* *} 0.40$ & ${ }^{* *} 0.58$ & 0.03 & ${ }^{* *}-0.48$ & ${ }^{* *} 0.53$ & ${ }^{* *} 0.92$ & ${ }^{* *} 0.38$ & -0.05 & ${ }^{* *}-0.50$ \\
\hline JuvF II & ${ }^{\star *} 0.73$ & -0.23 & ${ }^{* *}-0.40$ & *0.30 & -0.08 & ${ }^{* *}-0.49$ & -0.11 & 0.24 & ${ }^{* *} 0.80$ & -0.03 & ${ }^{* *}-0.60$ & ${ }^{* *} 0.44$ & ${ }^{\star *} 0.91$ & 0.15 & ${ }^{*}-0.27$ & ${ }^{* *}-0.41$ \\
\hline CopM I & ${ }^{* \star} 0.78$ & -0.20 & ${ }^{* *}-0.46$ & ${ }^{*} 0.29$ & -0.15 & ${ }^{* *}-0.55$ & -0.07 & 0.19 & ${ }^{* \star} 0.85$ & -0.04 & ${ }^{* *}-0.63$ & ${ }^{* *} 0.41$ & ${ }^{\star \star} 0.89$ & 0.07 & ${ }^{*}-0.33$ & ${ }^{* *}-0.37$ \\
\hline PrepF I & ${ }^{* *} 0.72$ & -0.18 & ${ }^{* *}-0.37$ & ${ }^{*} 0.27$ & -0.06 & ${ }^{* *}-0.52$ & -0.07 & ${ }^{*} 0.27$ & ${ }^{* *} 0.80$ & 0.02 & ** -0.58 & ${ }^{* *} 0.48$ & ${ }^{* *} 0.90$ & 0.17 & -0.25 & ${ }^{* *}-0.41$ \\
\hline PrepF II & ${ }^{\star \star} 0.84$ & -0.22 & ${ }^{* *}-0.54$ & ${ }^{*} 0.30$ & -0.21 & ${ }^{* *}-0.56$ & -0.07 & 0.13 & ${ }^{\star \star} 0.89$ & -0.10 & ${ }^{* *}-0.70$ & ${ }^{* *} 0.35$ & ${ }^{\star \star} 0.87$ & -0.01 & ${ }^{* *}-0.38$ & ${ }^{* *}-0.37$ \\
\hline CopF I & ${ }^{*} 0.33$ & ${ }^{*}-0.32$ & 0.05 & 0.26 & ${ }^{\star \star} 0.40$ & -0.03 & ${ }^{*}-0.32$ & ${ }^{\star *} 0.54$ & ${ }^{\star *} 0.34$ & 0.10 & ${ }^{* *}-0.38$ & ${ }^{* *} 0.58$ & ${ }^{\star \star} 0.84$ & ${ }^{* \star} 0.58$ & 0.20 & ${ }^{* *}-0.61$ \\
\hline CopF II & ${ }^{* *} 0.49$ & -0.26 & -0.12 & ${ }^{*} 0.31$ & 0.16 & ${ }^{*}-0.29$ & -0.21 & ${ }^{* *} 0.40$ & ${ }^{* \star} 0.56$ & 0.07 & ${ }^{* *}-0.40$ & ${ }^{* *} 0.55$ & ${ }^{\star *} 0.91$ & ${ }^{* *} 0.41$ & -0.04 & ${ }^{* *}-0.45$ \\
\hline CopM II & -0.22 & -0.16 & ${ }^{* *} 0.52$ & 0.20 & ${ }^{* *} 0.57$ & 0.18 & ${ }^{*}-0.27$ & ${ }^{* *} 0.57$ & -0.14 & ${ }^{*} 0.27$ & 0.22 & ${ }^{* *} 0.59$ & ${ }^{* *} 0.55$ & ${ }^{* *} 0.79$ & ${ }^{* *} 0.42$ & ${ }^{*}-0.31$ \\
\hline CopM III & ${ }^{*} 0.31$ & -0.20 & 0.06 & ${ }^{*} 0.29$ & 0.25 & -0.23 & -0.20 & ${ }^{* *} 0.45$ & ${ }^{* *} 0.41$ & 0.15 & -0.20 & ${ }^{* *} 0.60$ & ${ }^{* *} 0.85$ & ${ }^{* *} 0.53$ & 0.05 & ${ }^{* *}-0.37$ \\
\hline CopM IV & 0.07 & -0.16 & ${ }^{*} 0.29$ & 0.23 & ${ }^{* \star} 0.42$ & -0.07 & -0.21 & ${ }^{* \star} 0.55$ & 0.18 & 0.24 & 0.00 & ${ }^{* *} 0.64$ & ${ }^{* \star} 0.74$ & ${ }^{* *} 0.68$ & 0.24 & ${ }^{* *}-0.37$ \\
\hline OvF & ${ }^{* *} 0.46$ & ${ }^{*}-0.32$ & -0.09 & ${ }^{*} 0.32$ & 0.26 & -0.15 & ${ }^{*}-0.29$ & ${ }^{* *} 0.45$ & ${ }^{* \star} 0.48$ & 0.04 & ${ }^{* *}-0.45$ & ${ }^{* *} 0.54$ & ${ }^{* *} 0.90$ & ${ }^{* *} 0.46$ & 0.05 & ${ }^{* *}-0.55$ \\
\hline
\end{tabular}




\section{DISCUSSION}

The developmental stages as defined above were recorded in different percentages at four of five sampling sites (1, 3, 4, and 5). No manca stages were recorded in the winter 1995 when, during that time, the water temperatures registered were the lowest (Table 1). Modlin [24] also reported the absence of manca II stages for the tanaidacean Hargeria rapax (Harger, 1879) during the winter. The almost permanent presence of the manca stages; the juvenile males and females I and II; the copulatory males I, II, III and IV; the preparatory females I and II and the copulatory I and II and ovigerous females during all seasons suggested that Sinelobus stanfordi reproduction was very likely continuous throughout the year, as the results from [25] confirmed for the comparable habitats on the Argentine coast of the Río de la Plata estuary. This phenomenon does not occur in populations of tanaidaceans from higher latitudes such as, for example, Heterotanais oerstedi (Krøyer) and Tanais cavolinii (Milne-Edwards) $[26,27]$. Neither did Leite [28] encounter a strictly (because their findings not be same throughout the entire year) seasonal reproduction in Kalliapseudes schubarti Mañé-Garzon, 1949 from the the Brazilian Araça-Bay region of São Sebastião since that species exhibited larval peaks in both the spring and the winter. The highest larval production of $S$. stanfordi in the Nature Reserve Isla Martín García occurred in the spring of 1996 (Fig. 2), with water temperature at that time ranging from 22 to $29.5^{\circ} \mathrm{C}$. Though some lower values of larval stages were reported in the summer of 1995 and in the autumn of 1995 and 1997. Females either with or without ovisacs occurred quite variably, while females with eggs in the marsupium were generally scarce, being present values lower than $3 \%$ of the population (summer, 1995).Essentially the same representation of females was observed by [29].

The size distribution of the postmarsupial stages of the S. stanfordi population of Martín García de $S$. Stanfordi Island was similar to that recorded by [22] for their population under laboratory conditions. In addition, similar to our observations (Fig. 3), [29] found an overlap of sizes; while the stages of the females and the copulatory males II and IV in the present work reached larger respective size than did the corresponding stages in that laboratory population, wich difference had already been predicted by [22].
The fecundity of Sinelobus stanfordi did not reveal any significant relationship between female size and the number of eggs produced $\left(r^{2}\right.$ $=0.2164, \mathrm{n}=19)$, though we need to iterate that our sample was small. With a total sample of 41 individuals, [28] did not obtain significant results either $\left(r^{2}=0.072\right)$, though those authors attributed that statistical outcome to the loss of eggs during sieving.

The number of males was constant throughout the study period, which consistency also supports the idea of the aseasonal reproduction. The copulatory males (I-IV) were generally found at percentages between 7 to 35 with a peak of the copulatory male IV of $27 \%$ occurring in the summer 1996.

The sex-ratio deviations expected for Sinelobus stanfordi agreed with the interpretation of field and experimental data on $H$. rapax [24]. In the winter of 1995 and in the summer of 1996, the population density was low (Table 2.), but the sex ratio did not deviate significantly from the expected proportion (i. e., 1:1). Although [30] did not report the sex ratio for Leptochelia dubia, he did mention that higher percentages of males were recorded when the population density decreased, which result would agree with our own data on S. stanfordi. In contrast, the sex ratio for $K$. schubarti became skewed towards females, but in a lower proportion than in $L$. dubia or S. stanfordi [28]. Sex- ratio deviations would therefore seem to be a common phenomenon among the tanaidaceans.

With respect to the relantionship between environmental variables of the water and the population of $S$. stanfordi in the Nature Reserve, we found the average electrical conductivity of the island's littoral waters at $160.24 \mu \mathrm{S} . \mathrm{cm}^{-1}$ to be considerably lower than the optimum for the species (i. e., $658 \mu$ S. $\mathrm{cm}^{-1}$ ) cited by [31]. Nevertheless, that difference did not seem to be a limitation for the development of the population. According to the results of the Pearson correlation analysis, the conductivity did not correlate with the presence of all stages of $S$. stanfordi, except the examples of the juvenile male I $(0.30, p<0.05)$, the juvenile female I $(0.29$, $p<0.05)$, the copulatory female $\mathrm{I}$ and the ovigerous female $(0.32, p<0.05)$.

The $\mathrm{pH}$ of the littoral water of the island had values that slightly exceeded neutrality except at Site 4 and in general were between the optimal values and the lower limit for $S$. stanfordi cited by 
[31]. The behavior with respect to $\mathrm{pH}$ for almost all the stages of postmarsupial development was characterized by significant positive correlations (Table 2). The soluble reactive phosphorous and the $\mathrm{NO}_{3}^{-}$, were both around the lowest level of tolerance, while the $\mathrm{N}_{4}^{+}$was close to the optimal value. The dissolved oxygen concentrations registered in the littoral water of the Nature Reserve (86 to $98 \%$ ), were near the optimum indicated for the species by [31].

In comparison with the values corresponding to the Southern Coastal Strip of the Río de la Plata estuary we would conclude that, in general, the temperature and general thermal characteristics of the system are decidedly variable over time being influenced by seasonal variation and the dynamics of the ecosystem; while the average conductivity of the littoral waters of the island was lower than the average reported for the water of the Southern Coastal Strip (at $\left.259 \mu \mathrm{S} . \mathrm{cm}^{-1}\right)$. According to the quality guidelines established for the protection of aquatic life in the river, depending on the different uses of that resource; a $\mathrm{pH}$ range of 6.5 to 8.5; and a dissolved oxygen concentration of at least $5 \mathrm{mg}^{-\mathrm{L}^{-1}}$ was defined as the Use IV category (Water quality of the FCS Río de la Plata, 1997); wich criteria would be compatible with the values for the island's littoral water that have been recorded in the present study [32].

The lack of significant differences among the sampling sites would be attributed to the similar characteristics of their sediments (i. e., sandysilt) and the presence of vegetation-there, mainly reedy areas with $S$. californicus. In that regard, Site 3 was the most constant whit respect to the presence of $S$. stanfordi, because that site had the largest reedy area, whereas Site 2, having sandy sediments without vegetation, contained no individuals on any of the sampling occasions. The results of these analysis on the island revealed that $S$. stanfordi preferred a habitat with sandy-silt sediments containing the $S$. californicus. The studies carried out by [25], on the river's coast also reported this same preference of $S$. stanfordi for vegetated habitats. We need to stress, though, that the densities of $S$. stanfordi in most of our study area were higher (e. g., at Site 5 in Autumn-95, over 10,548.14 ind. $\mathrm{m}^{-2}$ ) than those reported by [31]. Giambiagi [33], however, found this species to be an epizoic form dwelling on shells of Anodontites trapezialis Lam. in the Río Santiago (located on the Argentine coast of the Río de la Plata estuary) and also on rocky substrates in Conchillas (geographical departament of Colonia, Uruguay). Moreover, [34] studying a Japanese lagoon concluded that $S$. stanfordi's distribution was influenced more by the structure of the sediment than by other environmental conditions so that this tanaidacean inhabited mainly the fine layer of sandy-silt sediments, in addition to being abundant under the algae Polysiphonia sp. Consequently, S. stanfordi would appear to enjoy a wide range of substrates to select from for building its tubes and developing its life cycle.

\section{CONCLUSION}

The developmental stages of S. stanfordi were recorded in different percentages in littoral waters of the Nature Reserve.

No manca stages were recorded in the winter-95 (the water temperatures registered were the lowest).

The almost permanent presence of the manca stages, the juvenile males and females, the copulatory males, the preparatory, the copulatory and the ovigerous females during all seasons suggested that Sinelobus stanfordi reproduction was very likely continuous throughout the year.

The fecundity of Sinelobus stanfordi did not reveal any significant relationship between female size and the number of eggs produced. The sex ratio was 3.04: 1 in favour of females.

With respect to the relationship between the environmental variables of the water and the population of $S$. stanfordi we found the average electrical conductivity of the island's littoral waters to be considerably lower than the optimum for the species. Nevertheless, that difference did not seem to be a limitation for the development of the population.

The $\mathrm{pH}$ of the littoral water of the island had values that slightly exceeded neutrality except at Site 4 and in general were between the optimal values and the lower limit for $S$. stanfordi. The behavior with respect to $\mathrm{pH}$ for almost all the stages of postmarsupial development was characterized by significant positive correlations.

The soluble reactive phosphorous and the $\mathrm{NO}_{3}^{-}$, were both around the lowest level of tolerance, 
while the $\mathrm{N}_{4}^{+}$was close to the optimal value. The dissolved oxygen concentrations registered in the littoral water of the Nature Reserve were near the optimum indicated for the species.

S. stanfordi preferred a habitat with sandy-silt sediments containing the $S$. californicus for building its tubes and developing its life cycle.

\section{ETHICAL APPROVAL}

As per international standard written ethical permission has been collected and preserved by the authors.

\section{ACKNOWLEDGEMENTS}

Financial support for this work was provided by an institutional grant from the Comisión de Investigaciones Científicas de la Provincia de Buenos Aires (CIC) and Facultad de Ciencias Naturales y Museo, Universidad Nacional de La Plata (Proyect 11/N470). The authors wish to thank to Dr. Donald Haggerty, a career investigator and native English speaker, edited the final version of the manuscript.

\section{COMPETING INTERESTS}

Authors have declared that no competing interests exist.

\section{REFERENCES}

1. Ravizza GB. Main geological aspects of the Quaternary on Martín García Island, Río de la Plata Superior. Rev. Asoc. Arg. Geol. 1984;39:125-130. Spanish.

2. Damborenea MC, César II, Armendáriz LC. Species of Temnocephala (Platyhelminthes Temnocephalidae) of Martín García Island, Buenos Aires, Argentina. Neotropica. 1997;43(109110):123-124. Spanish.

3. Armendáriz LC, César II, Damborenea MC. Oligochaetes in lentic environments of the Natural and Historical Reserve of Martín García Island, Río de la Plata Superior, Argentina. Nat. Neotropic. 2000;31(1/2):73-79. Spanish.

4. Armendáriz LC, César II. The distribution and ecology of littoral Oligochaeta and Aphanoneura (Annelida) of the Natural and Historical Reserve of Martín García Island,
Río de la Plata River, Argentina. Hydrobiology. 2001;463:207-216.

5. César II. Annelida (Oligochaeta and Aphanoneura) from the Natural Reserve of Martín García Island (Upper Río de la Plata estuary, Argentina): Biodiversity and response to environmental variables. Braz. J. Biol. 2014;74(1):128-136.

DOI:http://dx.doi.org/10.1590/bjb.2014.002 2.

6. César II, Martín SM, Gullo SB, Liberto R. Biodiversity and ecology of Hirudinea (Annelida) from the Natural Reserve of Martín García Island, Río de la Plata River, Argentina. Braz. J. Biol. 2009;69(4):11071113.

7. Fernández LA, López Ruf M. Coleoptera and Heteroptera aquatic and semi-aquatic of Martín García Island (Province of Buenos Aires). Physis (Buenos Aires.), Sec. B. 1999;57:1-4.

8. César II, Armendáriz LC, Damborenea MC. Ostrácodos (Crustacea) from Martín García Island, Río de la Plata, Argentina. Nat. Neotropic. 2001;32:147-151. Spanish.

9. César II, Liberto R. Ostracoda. Possible indicators of environmental deterioration of the Martín García Island Multiple Use Reserve?. Science. 2008;3(5):99-109. Spanish.

10. Liberto, R, Mezquita, F, César II. Dynamics of pleustonic ostracod populations in small ponds on the Island of Martín García (Río de la Plata, Argentina). Hydrobiología. 2012;688(1):47-61.

11. Liberto R, César II, Mesquita-Joanes F. Postembryonic growth in two species of freshwater Ostracoda (Crustacea) shows a size-age sigmoid model fit and temperature effects on development time, but no clear temperature-size rule (TSR) pattern. Limnology. 2014. The Japanese Society of Limnology.

DOI:10.1007/S10201-013-0413-0. 1-13 pp.

12. Rumi A, Martín SM, Tassara MP, Darrigran G. Moluscos de agua dulce de la Reserva Natural e Histórica Isla Martín García, Río de la Plata, Argentina. Com. Soc. Malacol. Uruguay. 1996;7:7-12.

13. Rumi A, Gutiérrez Gregoric DE, Núñez V, César II, Roche MA, Tassara MP, et al. Freshwater Gastropoda from Argentina: Species richness, distribution patterns, and 
an evaluation of endangered species. Malacologia. 2006;49(1):189-208.

14. Martín SM, Negrete LHL. Primer registro de Heleobia guaranitica (Doering, 1884) (Gastropoda: Cochliopidae) en la Reserva Natural de Usos Múltiples Isla Martín García. Com. Soc. Malacol. Uruguay. 2006;9(89):71-73. Spanish

15. 15) Rumi A, Gutiérrez Gregoric DE, Roche A. Growth rates fitting using the von Bertalanffy model: analysis in natural populations of Drepanotrema spp. (Gastropoda: Planorbidae). Rev. Biol. Trop. 2007;55(2):559-567.

16. Martín SM. Individual growth Heleobia piscium in natural populations (Gastropoda: Cochliopidae) from the Multiple Use Natural Reserve Isla Martín García, Buenos Aires, Argentina. Braz. J. Biol. 2008;68(3):617-621.

DOI:http://dx.doi.org/10.1590/S151969842008000300020. PMid:18833484.

17. César II, Martín SM, Rumi A, Tassara MP. Mollusks (Gastropoda and Bivalvia) of the Multiple-Use Reserve Martín García Island, Río de la Plata River: biodiversity and ecology. Braz. J. Biol. 2012;72(1):110. DOI:http://dx.doi.org/10.1590/S151969842012000100014. PMid: 22437379

18. Martín SM, César II, Liberto $R$. Distribution of Deroceras reticulatum (Müller, 1774) (Pulmonata Stylommatophora) in Argentina with first record of the Reserva de Usos Múltiples Isla Martin Garcia, Río de la Plata superior. Braz. J. Biol. 2009;69(4):11151119. PMID: 19967182.

DOI:http://dx.doi.org/10.1590/S151969842009000500015

19. Lahitte HB, Hurrell JA. Plantas Hidrófilas de la Isla Martín García (Buenos Aires, República Argentina), (La Plata: Comisión de Investigaciones Científicas). 1996;236.

20. Villar C, Decabo L, Vaithiyanathan $P$, Bonetto C. River-floodplain interactions: nutrient concentrations in the Lower Paraná River. Arch. Hydrobiol. 1998;142:433433.

21. Anderson RO. A modified flotation technique for sorting bottom fauna samples. Limnol. Oceanog. 1959;4:223225.

22. Toniollo V, Masunari S. Postmarsupial develop-ment of Sinelobus stanfordi
(Richardson, 1901) (Tanaidacea: Tanaidae). Nauplius. 2007;15:15-41.

23. Elliot JM. Some methods for the statistical analysis of samples of benthic invertebrates, (Freshwater Biological Association. Scientific Publication $\left.N^{\circ} 25\right)$. 1983;158-450.

24. Modlin RF, Harris PA. Observations on the natural history and experiments on the reproductive strategy of Hargeria rapax (Tanaidacea). J. Crust. Biol. 1989;9:578586.

25. Ferreira AC, Ambrosio ES Rodrigues Capítulo A. Population ecology of Sinelobus stanfordi (Crustacea: Tanaidacea) in a temperate southern microtidal estuary. New Z. J. Mar. Fresh. Res; 2015.

DOI:http://dx.doi.org/10.1080/00288330.20 15.108991.

26. Bückle-Ramírez LF. Untersuchungen über die Biologie von Heterotanais oerstedi Krøyer (Crustacea, Tanaidacea). Zeit. Morph. Ökol. Tiere. 1965;55:714-782.

27. Johnson SB. Functional models, lifehistory and evolution of tube-dwelling Tanaidacea (Crustacea). (Lund: Department of Zoology, University of Lund). 1982;133.

28. Leite FPP, Turra A, Souza ECF. Population biology and distribution of the tanaid Kalliapseudes schubarti MañéGarzon, 1949, in an intertidal flat in Southeastern Brazil. Braz. J. Biol. 2003;63:469-479.

29. Ferreira AC, Ambrosio ES, Rodrigues Capítulo A. Population ecology of Sinelobus stanfordi (Crustacea: Tanaidacea) in a temperate southern microtidal estuary. New Zeal. J. Mar. Fresh. Res; 2015.

DOI:http://dx.doi.org/10.1080/00288330.20 15.108991.

30. Highsmith RC. Sex reversal and fighting behavior: Coevolved phenomena in a tanaid crustacean. Ecology. 1983;64:719726.

31. Ambrosio ES, Ferreira AC, Rodrigues Capítulo A. The potential use of Sinelobus stanfordi (Richardson, 1901) (Crustacea, Tanaidacea) as a biological indi-cator of water quality in a temperate estuary of South America. Limnetica. 2014;33:139152. 
32. Calidad de las aguas de la Franja Costera Sur del Río de la Plata (San Fernando Magdalena). 1a Ed. Editado por Consejo Permanente para el Monitoreo de la Calidad de las Aguas de la Franja Costera Sur del Río de la Plata, 1997. 157 pp + anexos I y II. ISBN 987-96599-02. Spanish.
33. Giambiaggi D. Una nueva especie de Tanais. Physis (Buenos Aires). 1922;6:249-253. Spanish.

34. Matsumasa M, Kurihara $Y$. Distribution patterns of benthic small crustaceans and the environmental factors in a brackish shallow-water lagoon, Gamõ Lagoon. Benthos Research. 1988;33-34:33-41.

(0) 2019 César and Becerra; This is an Open Access article distributed under the terms of the Creative Commons Attribution License (http://creativecommons.org/licenses/by/4.0), which permits unrestricted use, distribution, and reproduction in any medium, provided the original work is properly cited.

Peer-review history:

The peer review history for this paper can be accessed here: http://www.sdiarticle3.com/review-history/48081 